\title{
The effects of chronic SRIH-14 and octreotide administration on the pituitary-adrenal axis in adult male rats
}

\author{
S. Trifunović, B. Filipović, V. Ajdžanović, B. Šošić-Jurijević, M. Manojlović-Stojanoski, \\ N. Nestorović, N. Ristić, M. Sekulić, V. Milošević \\ Institute for Biological Research Siniša Stanković, Bulevar Despota Stefana, Belgrade, Serbia
}

$\because$

(C)2008 European Journal of Histochemistry

The effects of chronic treatments with SRIH-14 and octreotide on pituitary corticotropes (ACTH cells) and on the adrenal cortex of male Wistar rats were examined. Adult males received two daily s.c. injections of $20 \mu \mathrm{g} / 100 \mathrm{~g}$ of body weight of either SRIH-14 or octreotide for 28 consecutive days. ACTH cells were studied using a peroxidaseantiperoxidase immunocytochemical procedure. Morphometry was used to evaluate the changes in cell and nuclear volumes $\left(\mu \mathrm{m}^{3}\right)$ and volume densities (\%) of ACTHimmunoreactive cells. The adrenal cortex was analyzed by histological and morphometric methods. A significant $(p<0.05)$ decrease in body weight and in the absolute weights of the pituitary and adrenal glands was observed in both treated groups. Morphometric parameters of ACTH cells in both treated groups were not significantly $(p>0.05)$ different than in control rats. The absolute volumes of the adrenal gland and adrenal cortex were significantly $(p<0.05)$ decreased in both treated groups. The absolute and relative volumes of the zona glomerulosa (ZG), as well as the cellular and nuclear volumes of the ZG were significantly $(p<0.05)$ decreased in the both treated groups. In rats treated with SRIH-14 and octreotide, the absolute and relative volumes of the zona fasciculata (ZF) and zona reticularis (ZR), as well as their stereological parameters, did not change significantly $(p>0.05)$. The aldosterone levels in the SRIH-14 and ocreotide-treated groups were significantly $(p<0.05)$ decreased - by $13 \%$ and $19 \%$, respectively. The concentration of ACTH and corticosterone did not change significantly. Together, these findings show that SRIH-14 and octreotide administration affected the morphological characteristics of the adrenal ZG in a similar manner, and brought about a decrease in plasma aldosterone concentration. These treatments did not affect pituitary ACTH cells or adrenal ZF and ZR functioning.

Key words: SRIH-14, octreotid, ACTH cells, adrenal gland, stereology.

Correspondence: Svetlana Trifunović, M. Sci

Institute for Biological Research Siniša Stanković,

Bulevar Despota Stefana 142, 11060 Belgrade, Serbia

Tel.: +381.11.2078.320.

Fax +381.11 .2078 .320$

E-mail: lanat@ibiss.bg.ac.yu

Paper accepted on August 23, 2007

European Journal of Histochemistry

2008; vol. 52 issue 1 (Jan-Mar): 61-68
S omatostatin (somatotropin release-inhibiting hormone; SRIH) is a regulatory peptide produced by neuroendocrine, inflammatory and immune cells (Patel, 1999). It acts as an endogenous regulator of the secretory and/or proliferative responses of target cells (Patel, 1999). It affects growth hormone secretion by the pituitary (Brazeau et al.,1973), as well as the secretion of insulin, glucagon, gastrin and secretin (Arnold and Linkisch, 1980). SRIH was detected in different regions of the brain, in the pituitary, the gastrointestinal tract and endocrine pancreas, the thyroid and adrenal glands and kidneys (Epelbaum, 1994; Reichlin, 1983a,b).

SRIH is synthesized as part of a large precursor molecule which is enzymatically cleaved into a prohormone form that is further processed to yield two active forms - SRIH-14 and SRIH-28 (Reichlin, $1983 a, b)$. Hormone action in target cells is mediated by a family of G-protein-coupled receptors that contain seven transmembrane domains comprised of five distinct subtypes, named somatostatin receptors 1-5 (sst.-5). Different experimental approaches showed that different sst receptors are expressed in normal and in tumor tissues (Patel, 1999).

Octreotide is a synthetic somatostatin analogue that has found clinical use in cancer therapy and in treatments of gastrointestinal and hormonal hypersecretory disorders. Octreotide is a cyclic octapeptide that is more powerful than endogenous SRIH because of its extended half-life (Bauer et al., 1982; Lamberts et al., 1991). Octreotide binds with high affinity to sst 2 and sst 5 receptors, with a moderate affinity to subtype 3, but it does not bind to either subtypes 1 or 4 (Rossowski and Coy, 1994).

SRIH receptors were detected in all types of hormone-producing cells of the pituitary gland (Day et al., 1995). SRIH decreases the release of hormones from somatotropes (Brazeau et al.,1973; Milošević et al., 1994), lactotropes (Bjoro et al., 1988; Milošević et al., 1998), thyrotropes (Milošević et 
al., 2000) and gonadotrophic LH cells (Starčević et al., 2002). It also exerts a negative effect on the morphometric features of gonadotrophic FSH cells (Nestorović et al., 2001; Milošević et al., 2004).

The role of SRIH in the modulation of corticotropes (ACTH cells) is still unclear. In pathological states such as Addison's disease and ACTHproducing tumors, it suppresses elevated ACTH levels (Patel, 1999). However, in healthy male adult rats intracerebroventricular (ICV) application of SRIH does not affect either the morphometric features of pituitary ACTH cells or the plasma level of ACTH (Milošević et al., 1994). On the contrary, ICV treatment with octreotide exerts an inhibitory effect on the morphometric characteristics of ACTH cells (Milošević et al., 2003).

The adrenal gland could also be a potential target of direct SRIH action. Somatostatin receptors have been detected both in the rat adrenal cortex and medulla (Aguilera et al.,1982; Maurer and Reubi, 1986). In vitro studies showed that SRIH influences the secretion of aldosterone by blocking its response to angiotensin II but not to ACTH (Boscaro et al., 1982). Decreases of aldosterone levels were demonstrated after octreotide administration to rats with portal hypertension (Albillos et al., 1993) and in cirrhotic patients (Sabat et al., 1998; Kalamokis et al., 2005), suggesting that octreotide regulates angiotensin II and aldosterone secretions in certain conditions.

Bearing in mind the important clinical uses of the SRIH analog octreotide, its different actions compared to SRIH, as well as the significance of adrenal gland signaling during states of stress, the aim of this study was to investigate and compare the effects of chronic SRIH-14 and octreotide treatments on the morphofunctional features of pituitary ACTH cells and the adrenal cortex in adult male rats.

\section{Materials and Methods}

\section{Experimental animals}

Wistar adult male rats were bred in the Institute for Biological Research in Belgrade. The rats were housed in a controlled environment at $22 \pm 2^{\circ} \mathrm{C}$, with a $12 \mathrm{~h}$ light/12 $\mathrm{h}$ dark schedule. The animals were allowed food and water ad libitum. Food for laboratory rats was prepared in the Veterinarski zavod (Subotica, Srbija).

\section{Experimental protocol}

All experimental protocols were approved by the Local Animal Care Committee. They conformed to the recommendations provided in the Guide for the Care and Use of Laboratory Animals (1996, National Academy Press, Washington D.C.). The rats were divided into three experimental groups consisting of five animals per group. Rats from the first group were injected subcutaneously (s.c.) twice a day with $20 \mathrm{mg}$ SRIH-14 (NS 9129; Sigma, St. Louis, Mo., USA) per 100 g b.w. for 28 consecutive days (between the ages of 32 and 59 days). The dose regimen selected for SRIH-14 was based on that of Rebuffat et al. (1984), except that SRIH was administered every $12 \mathrm{~h}$ instead of every $8 \mathrm{~h}$. Rats from the second group received twice a day a s.c. injection of $20 \mu \mathrm{g}$ octreotide (Sandostatine, Novartis, Switzerland) per $100 \mathrm{~g}$ b.w. for 28 consecutive days (between the ages of 32 and 59 days). The third, control group was comprised of rats that were treated only with saline. All animals were killed under ether anesthesia $12 \mathrm{~h}$ after the last injection. The pituitary and adrenal glands were excised, fixed in Bouin's solution for 48 $h$, dehydrated and embedded in paraffin.

\section{Immunocytochemistry of pituitary corticotropes}

Five $\mu \mathrm{m}$ thick pituitary sections were immunocytochemically stained. Pituitary hormones were localized by the peroxidase-anti-peroxidase complex (PAP) method of Sternberger et al. (1970). Endogenous peroxidase activity was blocked by incubation in $9 \mathrm{mmol}$ hydrogen peroxide solution in methanol for $30 \mathrm{~min}$ at ambient temperature. Before application of a specific primary antiserum, nonspecific background staining was achieved by a 60 min incubation of the sections with a nonimmune, normal porcine serum diluted with phosphate buffered saline (PBS) pH 7.4. The sections were then overlaid with the appropriate dilutions of specific primary antibodies (hACTH antisera, Dako A/S, Glostrup, Denmark) for $24 \mathrm{~h}$ at room temperature. After washing in PBS, the sections were incubated for 60 min with the second antibody and swine-anti-rabbit IgG, for 45 min, rinsed with PBS for 10 min and incubated with rabbit PAP serum for $45 \mathrm{~min}$. Antibodies were visualized by incubating the sections in Tris-HCl-buffered saline $(0.5$ $\mathrm{mol} / \mathrm{l}, \mathrm{pH}$ 7.4), supplemented with 3,3-diaminobenzidine tetrachloride (DAB, Serva, Heidelberg, Germany) and $9 \mathrm{mmol} / \mathrm{l}$ hydrogen peroxide. Slides 
were thoroughly washed under running tap water, counterstained with hematoxylin, and mounted in Canada balsam (Alkaloid, Skopje, FYROM). Control sections were incubated either without a primary antiserum or with a nonimmune rabbit serum.

\section{Morphometric measurements in pituitary corti- cotropes}

Immunocytochemically stained sections of pituitaries that were cut through three tissue levels of the pars distalis were used for morphometric examinations. The cell volumes $\left(V_{c}\right)$, nuclear volumes $\left(V_{n}\right)$ and volume densities $\left(V_{v}\right)$ of ACTH cells were estimated under the light microscope (Carl Zeiss, Germany) at 1000x magnification on $5 \mu \mathrm{m}$ thick sections, using the $M_{42}$ multipurpose test system (Weibel, 1979). The volumes of ACTH-positive cells were expressed in $\mu \mathrm{m}^{3}$. The volume densities were presented as percentages of total pituitary cells in \%.

\section{Morphometric measurements in the adrenal gland}

The absolute volume of the glands was calculated on the basis of their weight, assuming an average specific gravity of $1.039 \mathrm{~g} \mathrm{~cm}^{-3}$ (Swinyard, 1938). In order to evaluate the volume densities of the adrenocortical zones, every tenth section ( $5 \mu \mathrm{m}$ thick) of the gland was analyzed at $125 x$ magnification with the multipurpose test system $M_{42}$ (Weibel, 1979).

The nuclear and cytoplasmic volumes of parenchymal cells were estimated under the light microscope at 1000x magnification on $5 \mu \mathrm{m}$ thick sections with the $\mathrm{M}_{42}$ multipurpose test system (Weibel, 1979). For each adrenal gland, a single paraffin section containing the zona medullaris was chosen and 30 test areas of the ZG and 50 test areas of both the ZF and ZR were analyzed.

\section{Hormone assays}

The plasma levels of adrenocorticotropic hormone in the control, SRIH-14-treated and octreotide-treated rats were measured with the chemiluminiscent enzyme immunometric assay IMMULITE ACTH (DPC, Los Angeles). Serum aldosterone levels were determined with the enzyme immunoassay Aldosterone ELISA (DRG International, Inc. USA). Serum corticosterone levels were determined with the Corticosterone Immunoassay (R\&D Systems Inc. USA).

\section{Statistical analyses}

The biochemical and morphometric data for each group were averaged and the SD of the means were calculated. One-way analysis of variance (ANOVA), followed by the multiple-range test of Duncan, were used for statistical comparisons between the groups. Values of $p$ less than 0.05 were considered statistically significant.

\section{Results}

\section{Measurements of body weight and absolute and relative pituitary and adrenal weights}

Significant $(p<0.05)$ decreases in body weight by $19 \%$ and $16 \%$ were observed after the last administration of SRIH-14 and octreotide, respectively (Table 1). The absolute weights of the pituitary glands were significantly $(p<0.05)$ decreased - by $22 \%$ and $19 \%$ in SRIH-14- and octreotide-treated animals, respectively (Table 1). The absolute weights of the adrenal glands were significantly $(p<0.05)$ decreased - by $23 \%$ and $21 \%$ in the SRIH-14- and octreotide-treated groups, respectively (Table 1). The relative weights of the pituitary and adrenal glands did not differ significantly between the SRIH-14- and octreotide-treated groups (Table 1).

\section{Immunopositive ACTH cells}

In control males, ACTH cells immunostained intensely, either individually or in groups located between the capillaries in the pituitary pars distalis. The ACTH cells were of irregular shape. They possessed eccentrically placed, ovoid nuclei and cytoplasmic processes between neighboring cells.

\begin{tabular}{|c|c|c|c|c|c|}
\hline \multirow[t]{2}{*}{ Groups } & \multirow[t]{2}{*}{$\begin{array}{c}\text { Body } \\
\text { weight, (g) }\end{array}$} & \multicolumn{2}{|c|}{$\begin{array}{c}\text { Absolute } \\
\text { weight, (mg) }\end{array}$} & \multicolumn{2}{|c|}{$\begin{array}{c}\text { Relative } \\
\text { weight, (mg \%) }\end{array}$} \\
\hline & & pituitary & adrenal & pituitary & adrenal \\
\hline Controls & $269.1 \pm 22.9$ & $9.1 \pm 0.1$ & $18.1 \pm 0.5$ & $3.4 \pm 0.3$ & $6.7 \pm 0.5$ \\
\hline SRIH-14 & $\begin{array}{c}217.2 \pm 19.2^{\mathrm{a}} \\
-19 \%\end{array}$ & $\begin{array}{c}7.1 \pm 0.6^{a} \\
-22 \%\end{array}$ & $\begin{array}{c}13.7 \pm 0.6^{a} \\
-23 \%\end{array}$ & $3.3 \pm 0.6$ & $6.2 \pm 0.5$ \\
\hline Octreotide & $\begin{array}{c}225.6 \pm 12^{a} \\
-16 \%\end{array}$ & $\begin{array}{c}7.3 \pm 0.7^{a} \\
-19 \%\end{array}$ & $\begin{array}{c}14.3 \pm 1.2^{\mathrm{a}} \\
-21 \%\end{array}$ & $3.2 \pm 0.3$ & $6.5 \pm 0.3$ \\
\hline
\end{tabular}

$($ mean $\pm S D ; n=5) ;{ }^{a}, p<0.05$ vs. controls 
The localization and shape of ACTH immunoreactive cells did not change in either treated or control rats (Figure $1 \mathrm{~A}, \mathrm{~B}, \mathrm{C}$ ).

The morphometric parameters are shown in Table 2. The volumes of ACTH cells and their nuclei in the SRIH-14- and ocreotide-treated groups were not

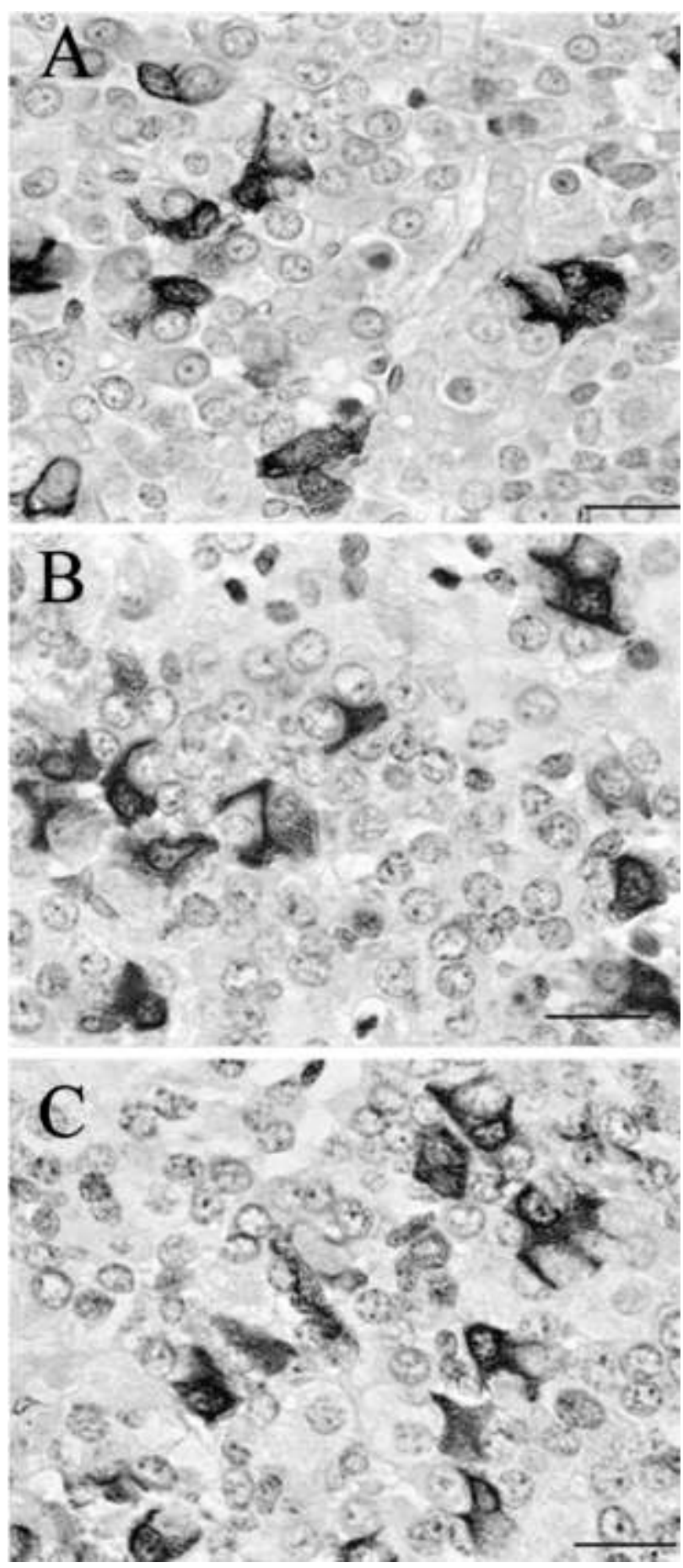

Figure 1. ACTH cells in A) control rats; B) rats treated with SRIH14; C) rats treated with octreotide. Bar, $20 \mu \mathrm{m}$. significantly ( $p>0.05)$ decreased compared to the control. Compared to the control, the volume density of the ACTH cells in the SRIH-14-treated group decreased significantly $(p<0.05)$ by $11 \%$, whereas in the octreotide-treated group the observed decrease was not significant ( $p>0.05)$.

The measured decrease in plasma ACTH levels with respect to the control was not statistically significant $(p>0.05)$ in either experimental group (Figure 2).

The morphometric parameters of the ACTH cells, as well as ACTH levels, did not differ significantly between the SRIH-14 and octreotide-treated groups.

\section{The adrenal gland}

The absolute volumes of the adrenal glands decreased significantly $(p<0.05)-$ by $24 \%$ and $20 \%$ in the SRIH-14- and octreotide-treated groups, respectively (Figure 3 ). Compared to the control, the absolute volumes of the adrenal cortices were significantly $(p<0.05)$ decreased - by $13 \%$ and $17 \%$ in the SRIH-14- and octreotidetreated groups, respectively.

The relative volumes of the adrenal cortices remained unchanged in both of the treated groups (Figure 4). The absolute volumes of the adrenal glands and the adrenal cortices did not differ significantly between the SRIH-14- and octreotide-treated groups.

\section{The adrenal cortex - histological and morphomet- ric findings}

\section{Zona glomerulosa ( $Z G$ )}

The $Z G$ is arranged in closely packed ovoidshaped cell clusters. The cells of the $Z G$ are relatively small, columnar or pyramidal, with oval nuclei.

Table 2. Effects of chronic SRIH-14 and octreotide treatments on the morphometric parameters of ACTH cells in male rats.

\begin{tabular}{lccc}
\hline Groups & $\begin{array}{c}\text { Volume of the } \\
\text { ACTH cells, } \\
\left(\mu m^{3}\right)\end{array}$ & $\begin{array}{c}\text { Volume of the } \\
\text { ACTH nuclei, } \\
\left(\mu m^{3}\right)\end{array}$ & $\begin{array}{c}\text { Volume } \\
\text { density of the } \\
\text { ACTH cells, (\%) }\end{array}$ \\
\hline Controls & $1044 \pm 40$ & $144 \pm 3$ & $17 \pm 1$ \\
SRIH-14 & $996 \pm 55$ & $141 \pm 4$ & $15 \pm 1^{\mathrm{a}}$ \\
Octreotide & $1033 \pm 31$ & $139 \pm 6$ & $-11 \%$ \\
\hline
\end{tabular}

$($ mean $\pm S D ; n=5) ;{ }^{a}, p<0.05$ vs. controls 
The overall shape of $Z G$ cells in both treated groups did not change (Figure $5 \mathrm{~A}, \mathrm{~B}, 5 \mathrm{C}$ ).

The absolute volumes of the ZG decreased significantly $(p<0.05)$ - by about $19 \%$ and $25 \%$ in the SRIH-14- and octreotide-treated groups, respec-

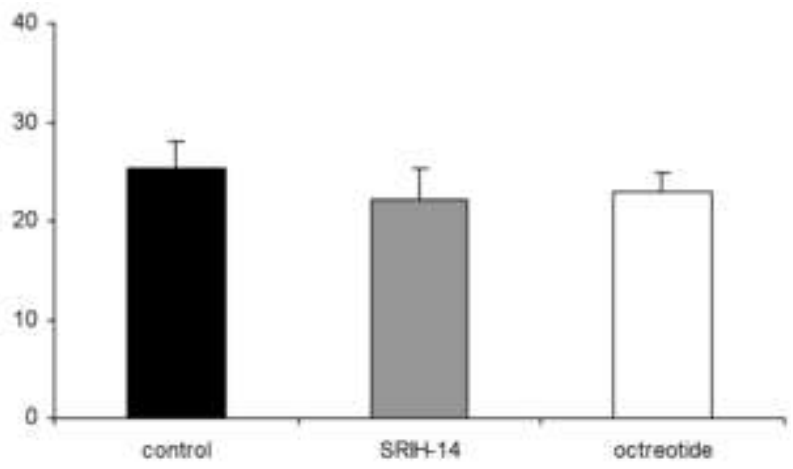

Figure 2. The effects of treatments with SRIH-14 and octreotide on blood ACTH concentrations $(\mathrm{pg} / \mathrm{mL}$ ) in male rats. (mean \pm SD; $n=5)$.

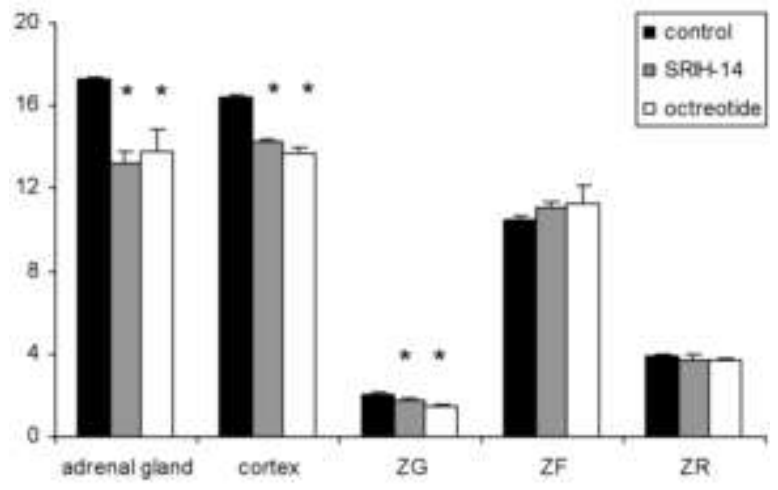

Figure 3. The absolute volume $\left(\mathrm{cm}^{3}\right)$ of the adrenal cortex, zona glomerulosa (ZG) and zona fasciculata (ZF) after treatments with SRIH-14 and octreotide in male rats. (mean \pm SD; $n=5$ ); ${ }^{a}, p<0.05$ vs. controls.

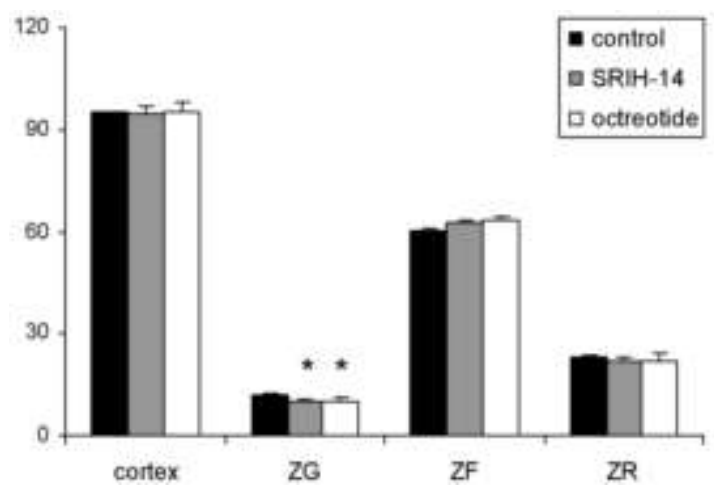

Figure 4. The relative volume (\%) of the adrenal cortex, zona glomerulosa (ZG) and zona fasciculata (ZF) after treatments with SRIH-14 and octreotide in male rats. (mean \pm SD; $n=5$ ); $a, p<0.05$ vs. controls. tively (Figure 3 ).

The relative volumes of the $Z G$ in both treated groups were significantly decreased $(p<0.05)$ - by about $13 \%$ and $16 \%$ in the SRIH-14- and octreotide-treated groups, respectively (Figure 4).
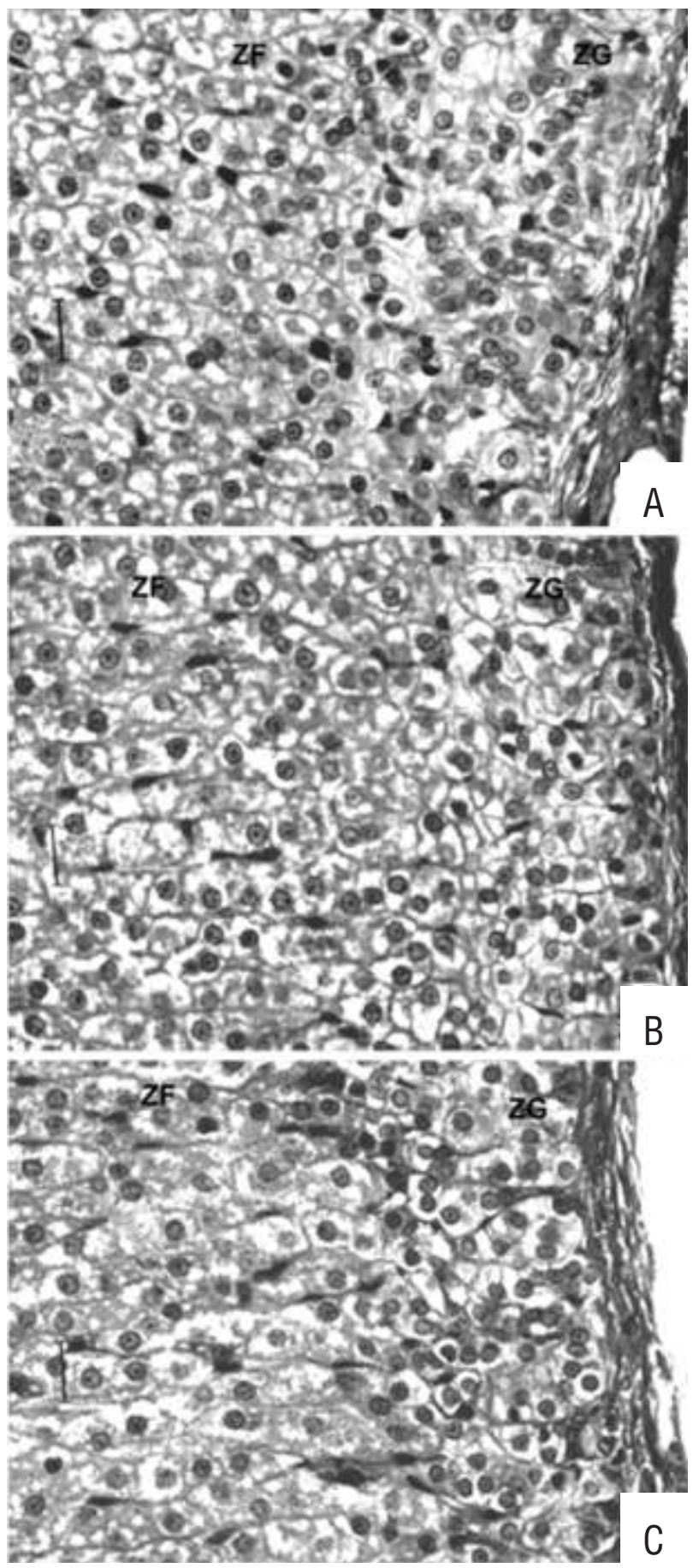

Figure 5. ZG and ZF in A) control rats; B) rats treated with SRIH14; C) rats treated with octreotide. Bar, $20 \mu \mathrm{m}$. ZG - zona glomerulosa; ZF - zona fasciculata. 
Stereological analysis showed that the volumes of the ZG cells and their nuclei in both treated groups were significantly $(p<0.05)$ decreased in comparison with the control (Table 3 ).

The serum levels of aldosterone significantly $(p<0.05)$ decreased - by $13 \%$ in the SRIH-14treated group and by $19 \%$ in the octreotide-treated group (Figure 6).

Zona fasciculata $(Z F)$ and zona reticularis $(Z R)$

The ZF is large and it is made up of polyhedral cells. The cells are arranged in long, straight, one to two cells thick cords separated by sinusoidal capillaries. The shapes and positions of the cells did not change after chronic treatments with either SRIH14 or octreotid (Figure 5A, B, 5C). The absolute and relative volumes and stereological parameters (cell and nuclear volumes) of the ZF and the ZR did not change (Figures 3 and 4; Table 3). Neither the SRIH-14- or octreotide-treated groups demonstrated significant $(p>0.05)$ increases in corticosterone serum levels (Figure 7 ).

The morphometric parameters of the ZG, ZF and $Z R$ cells and the aldosterone and corticosterone concentrations did not differ significantly between the SRIH-14- and octreotide-treated groups.

\section{Discussion}

The aim of this study was to examine the effects of chronic SRIH-14 and octreotide administration on the structure and function of the pituitary-adrenal axis in adult male rats.

Under our experimental conditions, a significant lowering of the body weight was detected after both treatments. These results are in agreement with our previous findings obtained after ICV administration of SRIH (Miloševic et al., 1996). Other authors have shown that SRIH reduces food intake both in man and in the rat (Lieverse at al. 1995; Scalera and Tarozzi, 1998).

A decrease of absolute pituitary weight after SRIH-14 and octreotide administration was observed whereas its relative weight remained unchanged. This result could be due to the significant decrease in volume density of somatotropes and lactotropes which together contribute to more than $60 \%$ of pituitary cells (Milošević et al., 1998). The ratio of the pituitary weight to the relative body weight did not change since both the absolute pituitary weight and the body weight decreased after the treatments.

The relative volume density of pituitary corticotrophes decreased significantly after the treatment with SRIH-14, while octreotide did not affect this stereological parameter. Other examined stereological parameters after both treatments were not significantly changed, and neither were the mean

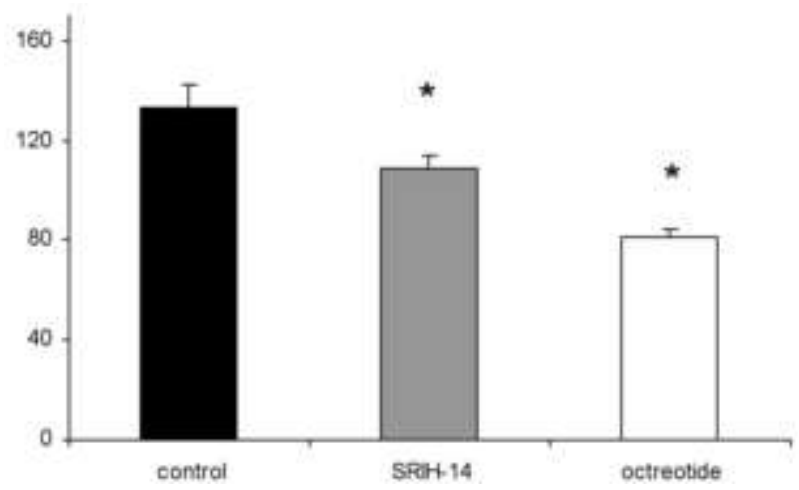

Figure 6. The effects of treatments with SRIH-14 and octreotide on aldosterone blood concentrations $(\mathrm{pg} / \mathrm{mL})$ in male rats. (mean $\pm \mathrm{SD} ; \mathrm{n}=5$ ); $\mathrm{a}, \mathrm{p}<0.05$ vs. controls

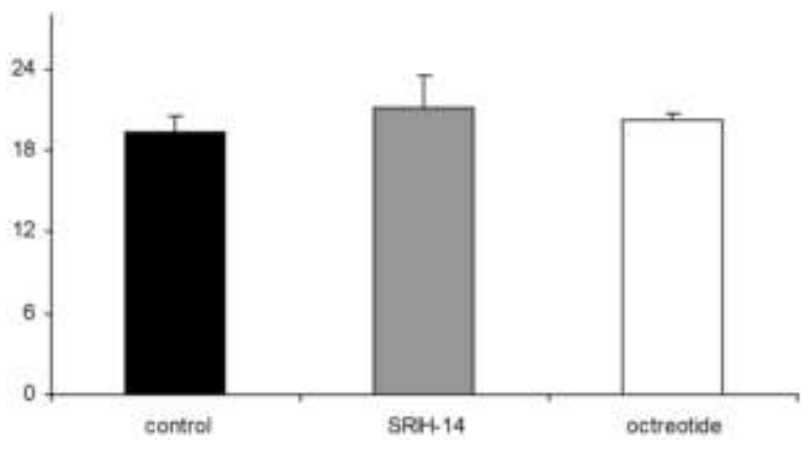

Figure 7. The effects of treatments with SRIH-14 and octreotide on corticosterone blood concentrations $(\mathrm{ng} / \mathrm{mL})$ in male rats. (mean \pm SD; $n=5$ ).

Table 3. Effects of chronic SRIH-14 and octreotide treatments on the morphometric parameters of male rat zona glomarulosa $(Z G)$, zona fasciculate (ZF) and zona reticulata (ZR).

\begin{tabular}{lcccccc}
\hline Groups & \multicolumn{3}{c}{ Volume of cells, $\left(\mu m^{3}\right)$} & \multicolumn{3}{c}{ Volume of nuclei, $\left(\mu m^{3}\right)$} \\
\cline { 2 - 7 } & $Z G$ & ZF & $Z R$ & $Z G$ & $Z F$ & $Z R$ \\
\hline controls & $909 \pm 43.6$ & $1521 \pm 40.3$ & $1038 \pm 34$ & $100 \pm 1.5$ & $140 \pm 8.2$ & $130 \pm 4$ \\
SRIH-14 & $825 \pm 30.4^{\mathrm{a}}$ & $158 \pm 14.7$ & $996 \pm 33$ & $87 \pm 1.8^{\mathrm{a}}$ & $140 \pm 1$ & $123 \pm 5$ \\
& $-10 \%$ & & & $-13 \%$ & & \\
octreotide & $823 \pm 16.1^{\mathrm{a}}$ & $1585 \pm 34.8$ & $980 \pm 40$ & $85 \pm 0.5^{\mathrm{a}}$ & $139 \pm 3.7$ & $120 \pm 1$ \\
& $-9 \%$ & & & $-15 \%$ & & \\
\hline
\end{tabular}

(mean $\pm S D ; n=5) ;{ }^{a}, p<0.05$ vs. controls. 
plasma ACTH levels, although a tendency towards decrease was observed. In vitro studies showed that native SRIH either did not have any effect or inhibited basal and $\mathrm{CRH}$-induced $\mathrm{ACTH}$ release from cultured pituitary cells obtained from normal rats (Brown et al., 1984; Nicholson et al., 1984). However, in At-T20 mouse and 7315 rat pituitary tumor cell lines SRIH exerted an inhibitory effect (Richardson and Schonbrunn, 1981; Lamberts et al. 1986). Octreotide did not affect basal and CRHinduced ACTH release in cultured normal rat pituitary cells (Lamberts et al., 1989), whereas chronic administration of octreotide inhibited the growth of ACTH-PRL-secreting pituitary tumors (Lamberts et al., 1986). It is well known that somatostatin activity is mediated through all five somatostatin receptor subtypes, while octreotide actions are mediated through only $\mathrm{sst}_{2}$ and $\mathrm{sst}_{5}$ (high affinity) and sst $_{3}$ (moderate affinity) receptors. $0^{\prime}$ Carroll and Krempels (1995) showed that in corticotropes the expression of all five sst mRNAs was low. Therefore, the weak and negative effect of SRIH-14 and the absence of octreotide-promoted effects under our experimental conditions could be due to the low expression of sst in pituitary ACTH cells.

At the level of adrenal gland, SRIH-14 and octreotide treatments brought about a significant decrease of all of the examined stereological parameters in the $Z G$ and of the serum level of aldosterone. However, in the ZF and ZR, the stereological parameters and the serum corticosterone levels were not affected by the treatments.

These findings are in agreement with the results obtained after multiple ICV treatments with SRIH14 and SRIH-28 which caused the ZG cells to atrophy (Milošević et al. 1996). Somatostatin can exert an inderect effect on ZG cells by influencing the rennin-angiotensin regulating system (in particular angiotensin II-induced aldosterone secretion; Aguilera et al., 1981). In addition, it is very likely that both SRIH and octreotide decreased the secretion of pituitary $\mathrm{GH}$ and $\mathrm{PRL}$ hormones, the endogenous stimulators of ZG cell growth and secretion (Mazzocchi et al.,1986; Rebuffat et al.,1986; Bjoro et al., 1988; de Bruin et al., 1992; Patel, 1999; Andersen et al., 1995). Since sst sst $_{2}$


as the expression of sst is extremely low in the ZF and ZR (O'Carroll, 2003), somatostatin probably directly affected the adrenal ZG as well.

In conclusion, our results showed that the admin- istration of both SRIH-14 and octreotide affected the morphological features of the adrenal $Z G$ in the same manner - by decreasing the total volume, as well as the cell and nuclear volumes. The treatments significantly lowered the plasma level of aldosterone. They did not change the structure and functioning of pituitary ACTH cells. The structure and functioning of adrenal ZF and ZR cells remained unchanged.

\section{Acknowledgment}

This work was supported by Ministry for Science and Enviromental Protection of Serbia, Grant number 143007B. Thanks Mr Granic (Promedia, Zrenjanin, Serbia) for donation.

\section{References}

Aguilera G, Harwood JP, Catt KJ. Somatostatin modulates effects of angiotensin II in adrenal glomerulosa zone. Nature 1981;292:2623.

Aguilera G, Parker DS, Catt KJ. Characterization of somatostatin receptors in the rat adrenal glomerulosa zone. Endocrinology 1982;111:1376-84.

Albillos A, Colombato LA, Lee FY, Groszmann RJ. Octreotide ameliorates vasodilatation and $\mathrm{Na}^{+}$retention in portal hypertensive rats. Gastroenterology 1993;104:575-9.

Andersen M, Hansen TB, Bollerslev J, Bjerre P, Schroder HD, Hagen C. Effect of 4 weeks of octreotide treatment on prolactin, thyroid stimulating hormone and thyroid hormones in acromegalic patients. A double blind placebo- controlled cross-over study. J Endocrinol Invest 1995; 18:840-6.

Arnold $\mathrm{R}$, Linkisch BG. Somatostatin and gastrointestinal tract. Clin Gastroenterol 1980;9:733-53.

Bauer W, Briner U, Doepfner W, Haller R, Huguenin R, Marbach P, et al. SMS 201-995 a very potent selective octapeptide analogue of somatostatin with prolonged action. Life Sci 1982;31:1133-40.

Bjoro T, Ostberg BC, Sand O, Torjesen PA, Penman E, Gordeladze J0, et al. Somatostatin inhibits prolactin secretion by multiple mechanisms involving a site of action distal to increased cyclic adenosine 3, 5,-monophosphate and elevanted cytosolic $\mathrm{Ca}^{2+}$ in rat lactotrops. Acta Physiol Scand 1988;133:271-82.

Boscaro M, Scaroni C, Edwards CR, Mantero F. Inhibitory effect of somatostatin on the aldosterone response to angiotenzin II: in vitro studies. J Endocrinol Invest 1982;5:173-7.

Brazeau $P$, Vale $W$, Burgus $R$, Ling $N$, Butcher $M$, Rivier $J$, et al. Hypothalamic polypeptide that inhibits the secretion of immunoreactive pituitary growth hormone. Science 1973;179:77-9.

Brown MR, Rivier C, Vale W. Central nervous system regulation of adrenocorticotropin secretion: role of somatostatins. Endocrinology 1984;114:1546-9.

Day R, Dong W, Panetta R, Krajcer J, Greenwood MT, Patel YC. Expression of mRNA for somatostatin receptor (sstr) types 2 and 5 in individual rat pituitary cells. A double labeling in situ hybridization analysis. Endocrinology 1995;136:5232-5.

de Bruin TWA, Kwekkeboom DJ, Van't Verlaat JW, et al. Clinically nonfunctioning pituitary adenoma and octreotide response to long term high dose treatment, and studies in vitro. J Clin Endocrinol Metab 1992;75:1310-7.

Epelbaum J, Dournaud P, Fodor M, Viollet C. The neurobiology of somatostatin. Crit Rev Neurobiol 1994;8:25-44.

Epelbaum J, Bertherat J, Prevost G, Kordon C, Meyerhof W, Wulfsen I, et al. Molecular and pharmacological characterization of somatostatin receptor subtypes in adrenal, extraadrenal, and malignant 
pheochromocytomas. J Clin Endocrinol Metab 1995;80:1837-44.

Kalamokis G, Economou M, Fotopoulos A, Al Bokharhii J, Pappas C, Katsaraki $A$, et al. The effects of chronic treatment with octreotide versus octreotide plus midodrine on systemic hemodynamics and renal hemodynamics and function in nonazotemic cirrhotic patients with ascites. Am J gastroenterol 2005;100:879-85.

Lamberts SW, Reubi JC, Uitterlinden P, Zuiderwijk J, van den Werff $P_{,}$ Van Hal P. Studies on mechanism of action of the inhibitory effect of somatostatin analog SMS 201-995 on growth of prolactin/adrenocorticotropin-secreting tumor 7315a. Endocrinology 1986;118: 2188-94.

Lamberts SW, Zuyderwijk J, den Holder F, van Koetsveld P, Hofland L. Studies on the conditions determining the inhibitory effect of somatostatin on adrenocorticotropin, prolactin and thyrotropin in release by cultured rat pituitary cells. Neuroendocrinology 1989;50:44-50.

Lamberts SW, Krenning EP, Reubi JC. The role of somatostatin and its analogs in the diagnosis and treatment of tumors. Endocr Rev $1991 ; 12: 450-82$.

Lieverse J, Jansen J, Masclee A, Lamers C. Effects of somatostatin on human satiety. Neuroendocrinology 1995;61:112-6.

Maurer R, Reubi JC. Somatostatin receptors in the adrenal. Mol Cell Endocrinol 1986;45:81-90.

Mazzocchi G, Robba C, Rebuffat P, Nussdorfer GC. Effects of prolactin administration on the zona glomerulosa of the rat adrenal cortex: stereology and plasma hormone concentrations Acta Endocrinol 1986;111:101-5.

Milošević V, Brkić B, Velkovski S, Starčević V. Somatostatin-induced changes of the ACTH and STH cells in the hypophysis of the male rats. Yugoslav Med Biohem 1994;13:102-6.

Milošević V, Velkovski S, Brkić B, Sekulić M, Lovren M, Starčević V, Severs WB. Inhibitory effects of centrally administered somatostatin on the adrenal zona glomerulosa in a male rats. Pharmacology 1996;53:369-75.

Milošević V, Brkić B, Velkovski S, Sekulić M, Lovren M, Starčević V et al. Morphometric and functional changes of the rat pituitary somatotropes and lactotropes after central administration of somatostatin. Pharmacology 1998:57:28-34.

Milošević V, Sekulić M, Brkić B, Lovren M, Starčević V. Effect of centrally administered somatostatin on pituitary thyreotropes in male rats. Histochem J 2000;32:565-9.

Milošević V, Manojlović M, Kostić N, Brkić B, Velkovski S, ŠošićJurjević B, et al. A somatostatin analogue octreotide inhibits pituitary ACTH cells in rat males. Iugoslav Physiol Pharmacol Acta 2003;39(1):25-30.

Milošević V, Nestorović N, Filipović B, Velkovski S, Starčević V. Centrally applied somatostatin influences morphology of pituitary FSH cells but not FSH release. Gen Physiol Biophys 2004;23:37580.

Nestorović N, Lovren M, Sekulić M, Filipović B, Milošević V. Effects of multiple somatostatin treatment on rat gonadotrophic cells and ovaries. Histochem J 2001;33:695-702.
Nicholson SA, Adrian TE, Gillham B, Jones MT, Bloom SR. Effect of hypothalamic neuropeptides on corticotrophin release from quarters of rat anterior pituitary gland in vitro. J Endocrinol 1984;100:21926.

O'Carroll AM, Krempels K. Widespread distribution of somatostatin messenger ribonucleic acid in rat pituitary. Endocrinology 1995; 136:5224-7.

0'Carroll AM. Localization of messenger ribonucleic acids for somatostatin receptor subtypes (sstr1-5) in the rat adrenal gland. J Histochem Cytochem 2003;51:55-60.

Patel YC. Somatostatin and its Receptor Family. Front Neuroendocrinol 1999;20:157-98.

Rebuffat P, Robba C, Mazzocchi G, Nussdorfer GC. Inhibitory effect of somatostatin on the growth and steroidogenic capacity of rat adrenal zona glomerulosa. J Steroid Biochem 1984;21:387-90.

Rebuffat P, Robba C, Mazzocchi G, Nussdorfer GG. Further studies on the effects of prolonged prolactin administration on the zona glomerulosa of the rat andrenal cortex. Res Exp Med 1986;186:307-15.

Reichlin S. Somatostatin. N Engl J Med 1983a;309:1495-501.

Reichlin S. Somatostatin (second of two parts). N Engl J Med 1983b;309:1556-63.

Richardon UI, Schonbrunn A. Inhibition of adrenocorticotropin secretion by somatostatin in pituitary cells in culture. Endocrinology 1981;108:281-90.

Rossowski WJ, Coy DH. Specific inhibition of rat pancreatic insulin or glucagons release by receptor-selective somatostatin analogs. Biochem Biophys Res Commun 1994;205:341-6.

Sabat M, Guarner C, Soriano G, Bulbena 0, Novella MT, Ortiz J, et al. Effect of subcutaneous administration of octreotide on endogenous vasoactive systems and renal function in cirrhotic patients with ascites. Dig Dis Sc 1998;43:2184-9.

Scalera G, Tarozzi G. Somatostatin administration modifies food intake, body weight, and gat motility in rat. Peptides 1998;19: 991-7.

Starčević V, Milošević $\mathrm{V}$, Brkić B, Severs WB. Somatostatin affects morphology and secretion of pituitary luteinizing hormone (LH) cells in male rats. Life Sci 2002;70:3019-27.

Sternberger LA, Hardy PHJr, Cuculius JJ, Meyer HG. The unlabelled antibody enzyme method of immunohistochemistry. Preparation and properties of soluble antigen-antibody complex (horseradish peroxidase-antihorseradish peroxidase) and its use in identification of spirochetes. J Histochem Cytochem 1970;18:315-33.

Swinyard C. Methods for volumetric determination of fresh endocrine gland. The anatomical record 1938;74:71-8.

Vinson G, Whitehouse B, Dell A, Etienne T, Morris H. Characterisation of on adrenal zona glomerulosa-stimulating component of posterior pituitary extracts as $\lambda$-MSH. Nature 1980;284:464-467

Weibel ER. Stereological methods. Vol 1. Practical methods for biological morphometry. Academic Press, London 1979, pp. 1-415. 